\title{
Adefovir dipivoxil-induced development of osteomalacia and Fanconi syndrome during the treatment of hepatitis B virus (HBV)-related cirrhosis
}

\begin{abstract}
Adefovir dipivoxil is a nucleotide analog reverse transcriptase inhibitor used to treat adult patients affected by HBeAg-positive and HBeAg-negative chronic hepatitis B and with clinical evidence of lamivudine-resistant hepatitis $B$ virus $(H B V)$. Adefovir administered at a dosage of $10 \mathrm{mg} /$ day is generally well tolerated, even if renal toxicity, type Fanconi syndrome, was reported during long-term treatments.

We report a case of osteomalacia with Fanconi syndrome and pathologic fracture of the femur related to long-time (67 months) adefovir treatment $(10 \mathrm{mg} /$ day) in a patient with compensated hepatitis $B$ virus $(\mathrm{HBV})$ cirrhosis (Child $5 A$ ) and with a previous normal renal function (estimated Glomerular Filtration Rate before adefovir $=78.26 \mathrm{ml} / \mathrm{min} / 1.73 \mathrm{~m}^{2}$; during adefovir treatment $=57.38 \mathrm{ml} / \mathrm{min} / 1.73 \mathrm{~m}^{2}$ ). The patient was switched to entecavir at a dose of $1 \mathrm{mg} /$ day, with both suppression of viremia and improvement of osteomalacia and Fanconi syndrome; the patient's follow-up is still ongoing after 22 months.
\end{abstract}

Keywords: Adefovir dipivoxil; Osteomalacia; Fanconi syndrome; HBV; Cirrhosis Sviluppo di osteomalacia e di sindrome di Fanconi durante il trattamento con adefovir in un paziente affetto da cirrosi epatica $\mathrm{HBV}$-correlata

CMI 2014; 8(4): 109-114

http://dx.doi.org/10.7175/cmi.v8i4.969

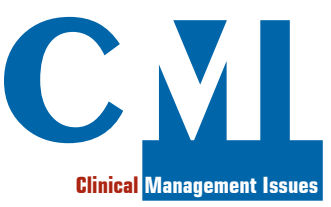

Case report
Rete Regionale di

informazione sul farmaco,

Azienda Ospedaliera

MaterDomini,

Catanzaro, Italy

2 Internal Medicine

Operative Unit, Azienda

Ospedaliera MaterDomini,

Catanzaro, Italy

Department of Health

Science, University

of Catanzaro and

Operative Unit of

Clinical Pharmacology and pharmacovigilance,

Azienda Ospedaliera

MaterDomini,

Catanzaro, Italy

\section{CASE REPORT}

A 55-year-old man (height $=175 \mathrm{~cm}$, weight $=68 \mathrm{~kg}$, Body Mass Index $=22.2 \mathrm{~kg} /$ $\mathrm{m}^{2}$ ) came to our observation in December 2012 due to the onset of bone pain, muscle cramps, and asthenia. Past history revealed that about 24 years before (1988) a chronic hepatitis B (anti-HBe positive) infection was diagnosed and 15 years later (2003) liver biopsy and endoscopy documented the presence of cirrhosis (Child 5A) with esophageal varices, respectively.

On 2005, a treatment with pegylated interferon $(180 \mu \mathrm{g} /$ week subcutaneously) was started (HBV-DNA = 10,000,000 IU/ml), but 18 months later (February 2007) for the persistence of high HBV-DNA levels $(\mathrm{HBV}-\mathrm{DNA}=352,000 \mathrm{IU} / \mathrm{ml})$, pegylat- ed-interferon was stopped and lamivudine $(100 \mathrm{mg} /$ day $)$ was administered. During the follow-up, three months later (May 2007),

Why we describe this case

Notwithstanding adefovir is considered safe at the dosage of $10 \mathrm{mg} /$ day, renal function must be carefully evaluated in order to prevent systemic disease and bone fracture. This case report could be useful in order to perform an appropriate prescription in HBV patients treated with adefovir and a risk of kidney or bone disease (e.g. patients taking non steroidal antinflammatory drugs, aminoglycosides, corticosteroids or menopausal women)
Corresponding author Luca Gallelli Department of Health Science, University of Catanzaro, Viale Europa, 88100 Catanzaro and Operative Unit of Clinical

Pharmacology and pharmacovigilance, Azienda Ospedaliera MaterDomini, Via T Campanella 115, Catanzaro, Italy. $\mathrm{Tel}+390961712322$; gallelli@unicz.it

\section{Disclosure}

The authors declare they have no competing financial interests concerning the topics of this article 
Table I. History of $\mathrm{HBV}$ infection and the related treatments

\begin{tabular}{|c|c|c|}
\hline Time & Test & Diagnosis or treatment \\
\hline 1988 & Microbiology & HBV infection (anti-HBe positive) \\
\hline 2003 & Liver biopsy and endoscopy & Cirrhosis (Child 5A) with esophageal varices F1 \\
\hline 2005 & $\mathrm{HBV}-\mathrm{DNA}=10,000,000 \mathrm{lU} / \mathrm{ml}$ & Pegylated interferon (180 $\mu \mathrm{g} /$ week) \\
\hline February २००७ & HBV-DNA $=352,000 \mathrm{IU} / \mathrm{ml}$ & Lamivudine (100 mg/day) \\
\hline May 2007 & HBV-DNA = $1025 \mathrm{IU} / \mathrm{ml}$ & $\begin{array}{l}\text { Lamivudine ( } 100 \mathrm{mg} / \text { day) + adefovir dipivoxil } \\
\text { (10 mg/day) }\end{array}$ \\
\hline July 2007 & HBV-DNA $<200 \mathrm{IU} / \mathrm{ml}$ & $\begin{array}{l}\text { Lamivudine (100 mg/day) + adefovir dipivoxil } \\
\text { (10 mg/day) }\end{array}$ \\
\hline February २००८ & HBV-DNA = $3770 \mathrm{lU} / \mathrm{ml}$ & Entecavir (1 mg/day) + adefovir dipivoxil (10 mg/day) \\
\hline May 2008 & HBV-DNA undetectable & Entecavir (1 mg/day) + adefovir dipivoxil (10 mg/day) \\
\hline
\end{tabular}

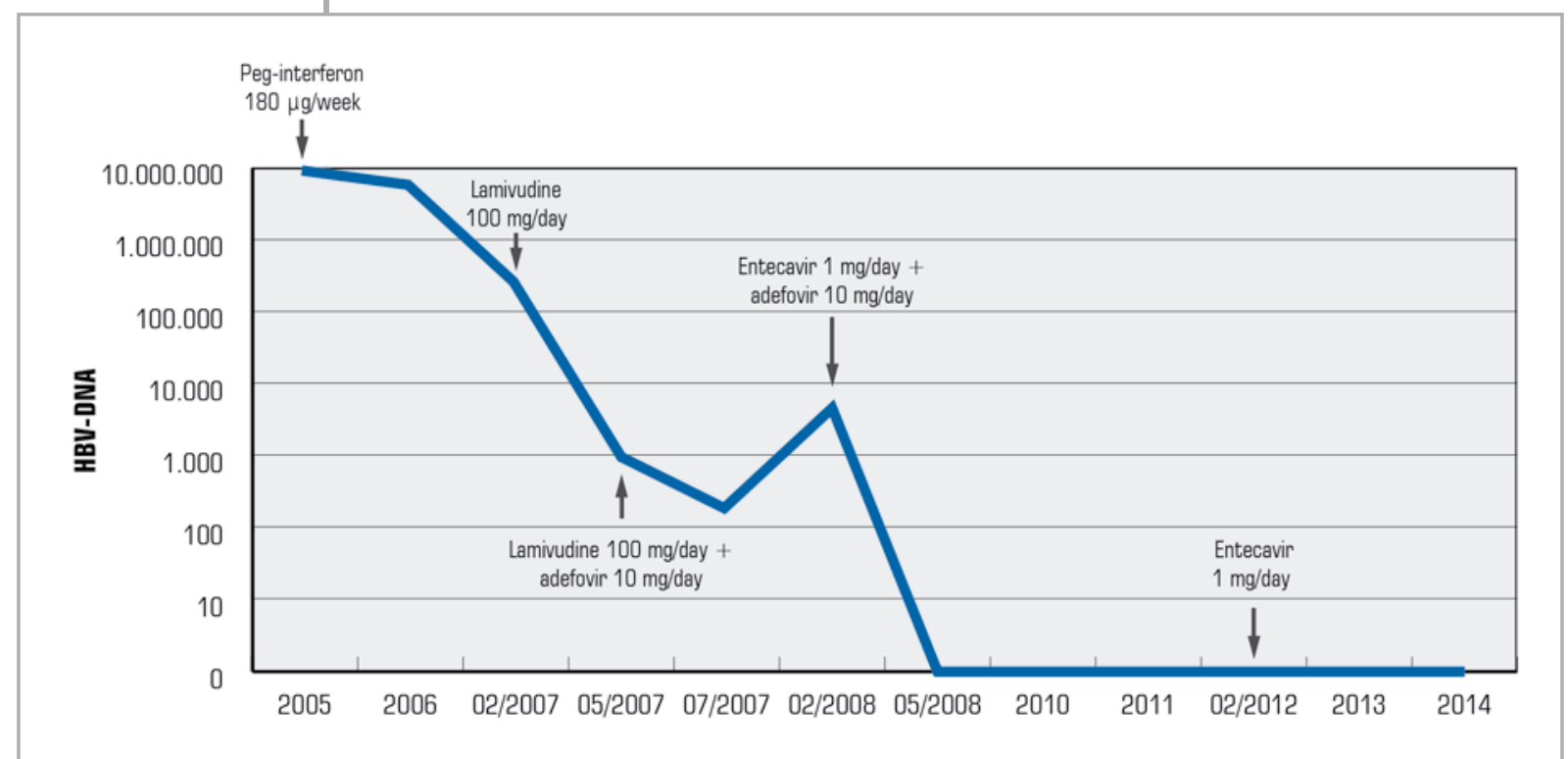

Figure 1. Timetable of $H B V-D N A$ levels during drug treatments the persistence of serum HBV-DNA levels $(1025 \mathrm{IU} / \mathrm{ml})$ was recorded, therefore adefo$\operatorname{vir}(10 \mathrm{mg} /$ day $)$ was added, thus attaining a virological suppression in about 2 months (HBV-DNA < $200 \mathrm{IU} / \mathrm{ml}$ ).

On February 2008, during the follow-up, an increase in serum HBV-DNA levels was detected $(3770 \mathrm{IU} / \mathrm{ml})$, lamivudine was stopped and entecavir ( $1 \mathrm{mg} /$ day $)$ was added with a complete suppression in three months (HBV-DNA undetectable). The history of $\mathrm{HBV}$ infection and the related treatments are reported in Table I, while Figure 1 shows the correlation between HBV-DNA levels and drug treatments.

On December 2010, biochemical evaluations revealed hypophosphoremia and glycosuria, without hyperglycemia (Table II).

On March 2011, the patient lamented muscular pain with walking difficulties and lower sensitivity in lower limbs and on Feb- ruary 2012, after an accidental fall occurred by sudden cramping pain of the left gastrocnemius, he reported a femoral neck fracture treated with arthroplasty. One week later, due to continuous muscular pain, he came to our observation as consultants. Clinical examination revealed an intense foot pain (visual analog pain scale, VAS $=8$ ) with difficulty to extend the lower limbs and hyper-excitability of tendon reflexes. At the time of this observation, the patient used no other drugs, while pain was treated with local patch of fentanyl. Somesthetic potential, electromyography, computer tomography and magnetic resonance image of spin and hip failed to show any muscular or skeletal disease. Cervical, dorsal and lumbosacral spine X-ray showed extensive demineralization of the bones; dual-energy X-ray absorptiometry (DXA) at all sites confirmed a low bone max density $\left(\mathrm{L} 1-\mathrm{L} 4=0.702 \mathrm{~g} / \mathrm{cm}^{2}\right.$, 


\begin{tabular}{|c|c|c|c|c|}
\hline & Normal range & $\begin{array}{l}\text { December } \\
2010\end{array}$ & $\begin{array}{c}\text { February } \\
2012\end{array}$ & $\begin{array}{c}\text { December } \\
2014\end{array}$ \\
\hline \multicolumn{5}{|l|}{ Blood tests } \\
\hline Phosphorus & $2.7-4.5 \mathrm{mg} / \mathrm{dl}$ & 2.1 & 0.9 & 3.2 \\
\hline Calcium & $8.5-10.5 \mathrm{mg} / \mathrm{dl}$ & 9.5 & 9.2 & 9.3 \\
\hline Glucose & $70-100 \mathrm{mg} / \mathrm{dl}$ & 92 & 90 & 90 \\
\hline Anion gap & 8-16 mEq/l & 11 & 11 & 11 \\
\hline Serum albumin & $38-47 \mathrm{~g} / \mathrm{dl}$ & 41 & 42 & 42 \\
\hline pH & 7.38-7.42 & 7.4 & 7.27 & 7.4 \\
\hline $\mathrm{pO}_{2}$ & 80-100 mmHg & 98 & 98 & 98 \\
\hline $\mathrm{pCO}_{2}$ & $35-45 \mathrm{mmHg}$ & 40 & 20 & 40 \\
\hline Creatinine clearance & $85-130 \mathrm{ml} / \mathrm{min}$ & 95 & 62 & 95 \\
\hline eGFR & $>90 \mathrm{ml} / \mathrm{min} / 1.73 \mathrm{~m}^{2}$ & 78.26 & 57.38 & 87.08 \\
\hline Serum creatinine & $0.7-1.2 \mathrm{mg} / \mathrm{dl}$ & 1 & 1.3 & 0.9 \\
\hline Potassium & $3.6-5 \mathrm{mEq} / \mathrm{l}$ & 4 & 3.32 & 4.2 \\
\hline Phosphate & 35-104 IU/I & 98 & 202 & 99 \\
\hline Alkaline phosphatase & 115-359 IU// & 340 & 1594 & 280 \\
\hline 25-hydroxy-vitamin D & $20-100$ ng/ml & 55 & 12 & 72 \\
\hline 1-25-dihydroxy-vitamin $D$ & $25-66 \mathrm{ng} / \mathrm{ml}$ & 48 & 19 & 52 \\
\hline Parathyroid hormone level & $10-65 \mathrm{pg} / \mathrm{ml}$ & 40 & 72 & 38 \\
\hline Serum-free $\mathrm{T}_{4}$ & $0.7-1.5 \mathrm{ng} / \mathrm{dl}$ & 1 & 0.95 & 0.96 \\
\hline TSH & $0.1-4.5 \mu \mathrm{lU} / \mathrm{ml}$ & 2.35 & 2.37 & 2.36 \\
\hline \multicolumn{5}{|l|}{ Urinalysis } \\
\hline Proteins & $<150$ mg/24h & 0 & 4520 & 110 \\
\hline Phosphate & $400-1300 \mathrm{mg} / 24 \mathrm{~h}$ & 795 & 1450 & 760 \\
\hline Uric acid & $250-750$ mg/24h & ५२० & 512 & 511 \\
\hline Calcium & $93-248$ mg/24h & 120 & 375 & 115 \\
\hline Glucose & $0 \mathrm{~g} / \mathrm{l}$ & 1 & 8.4 & 0 \\
\hline Potassium & 30-120 mEq/24h & 50 & 132 & 55 \\
\hline
\end{tabular}

T-score $=-4.2, \mathrm{Z}$-score $=-3.3$; left total hip $=0.423 \mathrm{~g} / \mathrm{cm}^{2}, \mathrm{~T}$-score $=-4.2$, Z-score $=-3.3$ ).

Arterial blood gas showed metabolic acidosis, while blood chemical evaluation revealed high levels of serum creatinine, phosphate, alkaline phosphatase and parathyroid hormone level, and low levels of creatinine clearance, phosphorus and potassium. Moreover, using a reversed phase (C18) high-performance liquid chromatography system (HPLC; UV detector 265 $\mathrm{nm}$, limit of detection $1,5 \mathrm{ng} / \mathrm{ml}$; intra-assay and inter-assay coefficients of variation for control $=8 \%$ ), low levels of 25-hydroxy-vitamin D and of 1-25-dihydroxy-vitamin D were detected.

Anion gap, serum albumin, serum-free $\mathrm{T}_{4}$ and TSH were within the normal rang- es, while urinalysis showed high levels of proteins, glucose, potassium, calcium, and phosphate (see Table II).

The kidney biopsy showed diffuse and severe tubulointerstitial nephritis with dense lymphoplasmocyte infiltrates. The absence of nausea, diarrhea, abnormal stools, weight loss, and gas, after 1 week of diet with standard food, as well as immunoglobulin A anti-tissue transglutaminase antibody evaluation (for celiac disease) and hydrogen breath test (for lactose intolerance) excluded a malabsorption syndrome.

A diagnosis of Fanconi syndrome with hypophosphatemic osteomalacia was postulated and using the Naranjo probability scale [1] we documented a possible association between adefovir and proximal tubulopathy (score $=7$ ). Adefovir was dismissed
Table II. Laboratory findings

eGFR = estimated Glomerular Filtration Rate, using the Modification of Diet in Renal Disease study group formula; $\mathrm{pCO}_{2}=$ partial pressure of carbon dioxide; $\mathrm{pO}_{2}=$ partial pressure of oxygen; TSH $=$ Thyroid-Stimulating Hormone 
Main questions a doctor should ask himself in this situation

- Can the patient take this drug?

- Are there other drugs that could impair renal (e.g. non steroidal antinflammatory drugs, aminoglycosides) or bone function (e.g. corticosteroids)?

- Have I evaluated the development of muscular pain?

- Have I evaluated the kidney function and the values of vitamin D?

- Can I change adefovir with entecavir alone?

(HBV-DNA < $200 \mathrm{IU} / \mathrm{mL})$, bicarbonates (12 mEq/day) and vitamin D (100,000 UI/ day for 7 days and then $800 \mathrm{UI} /$ day) were added with an improvement of muscular pain in two months (VAS = 2); the inability to walk disappeared in about six months, with normalization of laboratory text.

On October 2014, the patient was in entecavir monotherapy, microbiology assay documented a suppression of HBV-DNA $(<200 \mathrm{IU} / \mathrm{mL})$ and no side effects were recorded. A new follow-up performed on December 2014 revealed a significant improvement of both bone max density $\left(\right.$ DXA L1-L4 $=1.532 \mathrm{~g} / \mathrm{cm}^{2}, \mathrm{~T}$-score $=1.6$, $Z$-score $=2.3$; and left hip $=0.758 \mathrm{~g} / \mathrm{cm}^{2}$, $\mathrm{T}$-score $=-2.3, Z$-score $=-1.7)$ and biochemical assays (Table II).

\section{DISCUSSION}

Adefovir dipivoxil is a nucleotide analog reverse transcriptase inhibitor used to treat adult patients affected by $\mathrm{HBeAg-positive}$ and $\mathrm{HBeAg}$-negative chronic hepatitis $\mathrm{B}$ and with clinical evidence of lamivudine-resistant hepatitis B virus (HBV) $[2,3]$.

We report the development of tubules renal toxicity with osteomalacia and Fanconi syndrome during adefovir treatment.

Renal toxicity during the treatment with adefovir at the dosage of $30-120 \mathrm{mg} /$ day is uncommon; and some papers revealed that adefovir administered at common dosage of $10 \mathrm{mg} /$ day is well tolerated and does not cause alterations in creatinine clearance compared to placebo $[4,5]$.

However, a long-time treatment can result in an increase in serum creatinine in about $6-8 \%$ of patients [6,7], or in the development of renal toxicity [8-15].

Kim and colleagues [16], evaluating retrospectively 687 chronic hepatitis $B$ patients treated with adefovir alone $(18.2 \%)$ or in combination with lamivudine (81.8\%) for long-time periods (> 12 months) documented that about $10 \%$ developed renal toxicity after 27 months, which was mild in $77.8 \%$ of patients, moderate in $20.8 \%$, and severe in one patient.

In agreement, $\mathrm{Li}$ et al. [17] reported a case of a patient that developed Fanconi syndrome and hypophosphatemic osteomalacia associated with muscular weakness 4 years after the beginning of adefovir.

In our case, renal disease became symptomatic 67 months after the beginning of adefovir, with the development of musculoskeletal pain and difficulty in walking. The nephrotoxicity of adefovir is characterized by a decrease in serum phosphate levels with a modest increase in serum creatinine, related to proximal renal tubules dysfunction, as documented through laboratory texts.

Respect to other papers [8-17] that reported the association between adefovir and renal-toxicity, in the present case, using HPLC, we documented low plasma levels of vitamin $\mathrm{D}$ responsible of femoral fractures after an accidental fall related to muscle cramps.

Previously, Tanaka and colleagues [18] reported a 62-year-old man that developed pathological femoral fractures due to osteomalacia after 5 years from the beginning of adefovir, without deficiency of vitamin D.

Moreover, the development of hypophosphatemic osteomalacia associated with tenofovir has been also reported [19-21] and its features are similar to those of hypophosphatemic osteomalacia documented in our patient.

Some Authors documented that proximal renal tubules dysfunction, reducing the absorption of amino acids, glucose, bicarbonate, and phosphate, and the synthesis of 1,25-diidroxy-vitamin D3, induces the development of hypophosphatemic osteomalacia and Fanconi syndrome. Low levels of vitamin $\mathrm{D}$ increase the risk of bone loss, muscle aches, cramps, and fatigue [22,23].

The dismission of adefovir and the treatment with vitamin $\mathrm{D}$ induced the improvement of symptoms with the normalization of laboratory findings. 


\section{Keypoints}

- Adefovir is effective and generally well tolerated at the dosage of $10 \mathrm{mg} /$ day

- Even if unusual, the onset of renal toxicity may occur

- In presence of muscle pain, it is necessary to check the renal function and the level of vitamin D

- Renal function and vitamin D value must be carefully evaluated during the follow-up

- In the suspect of adefovir toxicity, it is advisable to replace it with another antiviral drug in agreement with guidelines

In agreement with our previous paper [24-26], using the Naranjo score, we documented a probable association between adefovir and clinical symptoms.

Treatment with entecavir in monotherapy maintained the viremic suppression without the development of side effects.

In conclusion, in patients with chronic hepatitis B treated with adefovir, blood and urinary analysis should be carefully evaluated in order to prevent the development of serious adverse drug reaction. Moreover, as well reported by De Socio et al. [21] for tenofovir, in presence of osteomalacia-related to adefovir a multidisciplinary approach is important in order to perform a rapid diagnosis and a timely treatment.

\section{REFERENCES}

1. Naranjo CA, Busto U, Sellers EM, et al. A method for estimating the probability of adverse drug reactions. Clin Pharmacol Ther 1981; 30: 239-45; http://dx.doi.org/10.1038/clpt.1981.154

2. Peters MG, Hann HH, Martin $\mathrm{P}$, et al. Adefovir dipivoxil alone or in combination with lamivudine in patients with lamivudine-resistant chronic hepatitis B. Gastroenterology 2004; 126: 91-101; http://dx.doi.org/10.1053/j.gastro.2003.10.051

3. Perrillo R, Hann HW, Mutimer D, et al. Adefovir dipivoxil added to ongoing lamivudine in chronic hepatitis B with YMDD mutant hepatitis B virus. Gastroenterology 2004; 126: 81-90; http://dx.doi.org/10.1053/j.gastro.2003.10.050

4. Marcellin P, Chang TT, Lim SG, et al. Adefovir dipivoxil for the treatment of hepatitis B e antigen-positive chronic hepatitis B. NEnglJMed 2003; 348: 808-16; http://dx.doi.org/10.1056/ NEJMoa020681

5. Hadziyannis SJ, Tassopoulos NC, Heathcote EJ, et al. Adefovir dipivoxil for the treatment of hepatitis B e antigen-negative chronic hepatitis B. NEnglJ Med 2003; 348: 800-7; http://dx.doi. org/10.1056/NEJMoa021812

6. Marcellin P, Chang TT, Lim SGL, et al. Longterm efficacy and safety of adefovir dipivoxil for the treatment of hepatitis Be antigen positive chronic hepatitis B. Hepatology 2008; 48: 750-8; http://dx.doi.org/10.1002/hep.22414

7. Hadziyannis SJ, Tassopoulos NC, Heathcote EJ, et al. Long-term therapy with adefovir dipivoxil for HBeAg-negative chronic hepatitis B for up to 5 years. Gastroenterology 2006; 131: 1743-51; http://dx.doi.org/10.1053/j.gastro.2006.09.020

8. Ha NB, Garcia RT, Trinh HN, et al. Renal dysfunction in chronic hepatitis B patients treated with adefovir dipivoxil. Hepatology 2009; 50: 727-34; http://dx.doi.org/10.1002/hep.23044

9. Tamori A, Enomoto M, Kobayashi S, et al. Add-on combination therapy with adefovir dipivoxil induces renal impairment in patients with lamivudine-refractory hepatitis B virus.J Viral Hepat 2010; 17: 123-9; http://dx.doi.org/10.1111/j.1365-2893.2009.01160.x

10. Jung YK, Yeon JE, Choi JH, et al. Fanconi's syndrome associated with prolonged adefovir dipivoxil therapy in a hepatitis B virus patient. Gut Liver 2010; 4: 389-93; http://dx.doi.org/10.5009/ gnl.2010.4.3.389

11. Wong T, Girgis CM, Ngu MC, et al. Hypophosphatemic osteomalacia after low-dose adefovir dipivoxil therapy for hepatitis B. J Clin Endocrinol Metab 2010; 95: 479-80; http://dx.doi. org/10.1210/jc.2009-2051 
12. Girgis CM, Wong T, Ngu MC, et al. Hypophosphataemic osteomalacia in patients on adefovir dipivoxil. J Clin Gastroenterol 2011; 45: 468-73; http://dx.doi.org/10.1097/ MCG.0b013e3181e12ed3

13. Fabbriciani G, de Socio GV, Massarotti M, et al. Adefovir induced hypophosphatemic osteomalacia. Scand J Infect Dis 2011; 43: 990-2; http://dx.doi.org/10.3109/00365548.2011. 581307

14. Shimohata H, Sakai S, Ogawa Y, et al. Osteomalacia due to Fanconi's syndrome and renal failure caused by long-term low-dose adefovir dipivoxil. Clin Exp Nephrol 2013; 17: 147-8; http:// dx.doi.org/10.1007/s10157-012-0762-8

15. Wu C, Zhang H, Qian Y, et al. Hypophosphatemic osteomalacia and renal Fanconi syndrome induced by low dose adefovir dipivoxil: a case report and literature review suggesting ethnic predisposition. J Clin Pharm Ther 2013; 38: 321-6; http://dx.doi.org/10.1111/jcpt.12050

16. Kim YJ, Cho HC, Sinn DH, et al. Frequency and risk factors of renal impairment during long-term adefovir dipivoxil treatment in chronic hepatitis B patients. J Gastroenterol Hepatol 2012; 27: 306-12; http://dx.doi.org/10.1111/j.1440-1746.2011.06852.x

17. Li L, Dong GF, Zhang X, et al. Adefovir dipivoxil-induced Fanconi syndrome and hypophosphatemic osteomalacia associated with muscular weakness in a patient with chronic hepatitis B. Nan Fang Yi Ke Da Xue Xue Bao 2011; 31: 1956

18. Tanaka M, Setoguchi T, Ishidou Y, et al. Pathological femoral fractures due to osteomalacia associated with adefovir dipivoxil treatment for hepatitis B: a case report.Diagnostic Pathol2012; 7: 108; http://dx.doi.org/10.1186/1746-1596-7-108

19. Mateo L, Holgado S, Mari-oso ML, et al. Hypophosphatemic osteomalacia induced by tenofovir in HIV-infected patients. Clin Rheumatol 2014 May 3 [Epub ahead of print]; http://dx.doi. org/10.1007/s10067-014-2627-x

20. Saidenberg-Kermanac'h N, Souabni L, Prendki V, et al. Normal plasma FGF23 levels kinetic in tenofovir-related hypophosphatemic osteomalacia in an HIV-infected patient with von Recklinghausen disease. Joint Bone Spine 2011; 78: 306-8; http://dx.doi.org/10.1016/j. jbspin.2010.11.007

21. De Socio GV, Fabbriciani G, Massarotti M, et al. Hypophosphatemic osteomalacia associated with tenofovir: a multidisciplinary approach is required. Mediterr J Hematol Infect Dis 2012; 4: e2012025; http://dx.doi.org/10.4084/mjhid.2012.025

22. Clarke BL, Wynne AG, Wilson DM, et al. Osteomalacia associated with adult Fanconi's syndrome: clinical and diagnostic features. Clin Endocrinol 1995; 43: 479-90; http://dx.doi. org/10.1111/j.1365-2265.1995.tb02621.x

23. Laing CM, Toye AM, Capasso G, et al. Renal tubular acidosis: developments in our understanding of the molecular basis. Int J Biochem Cell Biol 2005; 37: 1151-61; http://dx.doi. org/10.1016/j.biocel.2005.01.002

24. De Vuono A, Palleria $C$, Scicchitano F, et al. Skin rash during treatment with generic itraconazole. J Pharmacol Pharmacother 2014; 5: 158-60; http://dx.doi.org/10.4103/0976-500X.130086

25. Mumoli L, Gambardella A, Labate A, et al. Rosacea-like facial rash related to metformin administration in a young woman. BMC Pharmacol Toxicol 2014; 15: 3; http://dx.doi. org/10.1186/2050-6511-15-3

26. Caroleo B, Galasso O, Staltari $\mathrm{O}$, et al. Muscular damage during telbivudine treatment in a chronic hepatitis B patient. Muscles Ligaments Tendons J 2011; 1: 57-60 